\title{
Development of integrated ecological standards of sustainable forest management at an operational scale
}

\author{
by Daniel D. Kneeshaw ${ }^{1,2,3}$, Alain Leduc ${ }^{1}$, Pierre Drapeau ${ }^{1,4}$, Sylvie Gauthier ${ }^{1,5}$, David Paré ${ }^{1,5}$, \\ Richard Carignan ${ }^{6}$, René Doucet ${ }^{7}$, Luc Bouthillier ${ }^{2}$, and Christian Messier ${ }^{1}$
}

Within Canada, and internationally, an increasing demand that forests be managed to maintain all resources has led to the development of criteria and indicators of sustainable forest management. There is, however, a lack of understanding, at an operational scale, how to evaluate and compare forest management activities to ensure the sustainability of all resources. For example, nationally, many of the existing indicators are too broad to be used directly at a local scale of forest management; provincially, regulations are often too prescriptive and rigid to allow for adaptive management; and forest certification programs, often based largely on public or stakeholder opinion instead of scientific understanding, may be too local in nature to permit a comparison of operations across a biome. At an operational scale indicators must be relevant to forest activities and ecologically integrated. In order to aid decision-makers in the adaptive management necessary for sustainable forest management, two types of indicators are identified: those that are prescriptive to aid in planning forest management and those that are evaluative to be used in monitoring and suggesting improvements. An integrated approach to developing standards based on an ecosystem management paradigm is outlined for the boreal forest where the variability inherent in natural systems is used to define the limits within which forest management is ecologically sustainable. Sustainability thresholds are thus defined by ecosystem response after natural disturbances. For this exercise, standards are proposed for biodiversity, forest productivity via regeneration, soil conservation and aquatic resources. For each of these standards, planning indicators are developed for managing forest conditions while forest values are evaluated by environmental indicators, thus leading to a continuous cycle of improvement. Approaches to developing critical thresholds and corresponding prescriptions are also outlined. In all cases, the scale of evaluation is clearly related to the landscape (or FMU) level while the stand level is used for measurement purposes. In this view the forest should be managed as a whole even though forest interventions are usually undertaken at the stand level.

Key words: sustainable forest management, criteria and indicators, biodiversity, regeneration, soil conservation, aquatic resources, landscape level evaluation, planning and monitoring

Au Canada et internationalement, des critères et indicateurs de gestion durable des forêts ont été proposés afin de garantir la pérennité de l'ensemble des ressources provenant de la forêt. Bien que nationalement valables, ces indicateurs sont trop souvent inaptes pour permettre une juste évaluation et comparaison de l'état de la forêt prévalant dans une unité territoriale opérationnelle. Entre autre, plusieurs des indicateurs proposés apparaissent davantage adaptés pour décrire la situation nationale plutôt que celle caractérisant une unité particulière d'aménagement forestier. À l'intérieur des provinces, les législations existantes sont souvent trop rigides pour se prêter à une gestion adaptative. Les programmes de certification quant à eux semblent avant tout s'appuyer sur les opinions des intervenants locaux et risquent de ne générer que peu de standards permettant la comparaison des opérations forestière ayant cours dans un même biôme. Pour être mieux adaptés à une échelle opérationnelle, les indicateurs devraient davantage être rattachés aux opérations forestières, scientifiquement valables et intégrées écologiquement. Afin de faciliter la prise de décisions, les indicateurs de gestion durable ont été regroupés en deux catégories soit: les indicateurs prescriptifs qui adressent les problèmes de planification et les indicateurs évaluatifs dont la principale fonction est de permettre le suivi environnemental et son bilan. Le concept de gestion écosystémique au sein duquel la variabilité naturelle des écosystèmes détermine les seuils critiques à l'intérieur desquels les conditions forestières doivent être maintenues, a été retenu afin de d'établir les bases d'une approche intégrée au développement de standards en matière de gestion durable. Pour ce faire, des standards de biodiversité, de productivité forestière (par l'intermédiaire de la régénération), de conservation des sols, et pour les ressources aquatiques sont proposés. Pour chaque standard, des indicateurs de planification sont développés afin de faciliter le suivi des conditions forestières tandis que les valeurs forestières sont évalués à l'aide d'indicateurs environnementaux. Mis en interaction, ces indicateurs pourraient assurés une amélioration continue des opérations forestières visant une gestion durable de l'ensemble des ressources de la forêt. Lorsque nos connaissances actuelles le permettent, les seuils critiques et les prescriptions associées à ces indicateurs sont également abordés. Pour l'ensemble des indicateurs proposés, l'évaluation devrait toujours être établie à l'échelle du paysage (ou de l'unité forestière aménagée) alors que l'échelle du peuplement serait utile davantage au niveau de la prise de mesures. Dans cet optique, les décisions concernant le devenir de la forêt devraient toujours s'appuyer sur une connaissance de l'ensemble de sa condition et cela même si l'échelle à laquelle on intervient en forêt est davantage celle des peuplements.

Mots clés : gestion durable des forêts, critères et indicateurs, biodiversité, régénération, conservation des sols, ressources aquatiques, planification et suivi

\footnotetext{
${ }^{1}$ Groupe de recherche en écologie forestière interuniversitaire, Université du Québec à Montréal, C.P. 8888, Succ. Centre-ville, Montréal, Québec H3C 3P8. ${ }^{2}$ Département des sciences du bois et de la forêt, Pavillon Abitibi-Price, local 2110, Université Laval, Québec G1K 7P4.

${ }^{3}$ Current address: Direction de la recherche forestière, Ministère des Ressources naturelles, 2700 rue Einstein, Sainte-Foy, Québec G1P 3 W8.

${ }^{4}$ Chaire Industrielle, CRSNG-UQAT-UQAM en Aménagement Forestier Durable.

${ }^{5}$ Ressources naturelles Canada - Natural Resources Canada, Service canadien des forêts - Canadian Forest Service, Région du Québec-Quebec Region, C. P. 3800,1055 du P.E.P.S., Sainte-Foy, Québec G1V 4C7.

${ }^{6}$ Dept. de sciences biologiques, Universite de Montreal, C.P. 6128, succ. Centre-Ville, Montreal, Quebec H3C 3J7.

${ }^{7}$ Direction de la recherche forestière, Ministère des Ressources naturelles, 2700 rue Einstein, Sainte-Foy, Québec G1P 3W8.
} 


\section{Introduction}

Sustainable forest management (SFM) is replacing sustained yield forestry as the goal of many forest managers. This change was precipitated by increasing concerns from environmental non-governmental organizations (ENGOs) and the public about the impact of traditional timber management techniques on biodiversity, long-term productivity, indigenous peoples' rights, the continued survival and prosperity of forest-dependant communities, and other non-timber forest values. These concerns about forest management have led to numerous initiatives to better define and then insure the sustainability of all forest resources (UNCED 1992 Convention of Biological Diversity, 1993 Helsinki Process (for European nations) and the Montreal Process (for non-European nations)). The culmination of these meetings was the development of criteria and indicators for sustainable forest management. In Canada, the Canadian Council of Forest Ministers (CCFM) has described six criteria and 84 indicators of sustainable forest management. Their criteria include the 1) conservation of biological diversity, 2) ecosystem condition and productivity, 3) conservation of soil and water resources, 4) global ecological cycles, 5) multiple benefits of forests to society and 6) accepting society's responsibility (CCFM 1997).

Inspection of these criteria suggests that they can be divided into either biophysical or socio-economic issues. Discussions on the development of social indicators and public involvement in forest management decision-making have been undertaken elsewhere (Brunson 1996, Crossley 1996, Perez 1996, Schindler 1998, Côté and Bouthillier 1999). In this paper we focus on identifying and defining indicators of biophysical (or ecological) criteria. In our view, an understanding of biophysical issues is a crucial and underlying precept of SFM. The developed biophysical indicators can then be used as a base for discussions of their relative weights and importance in social systems (Hauffler et al. 1996).

Traditionally, Ministries of Natural Resources or Ministries of Forests were responsible for the management of forest lands in Canada. However, in the 1980s forest management was turned over to forest companies and the provincial ministries responsible for the forests became essentially regulatory and monitoring bodies (Kimmins 1992). These ministries now govern forest management through explicit, detailed, prescriptive regulations that cover all facets of forestry operations from culvert placements, to the size of riparian zones, to visual quality objectives. Although these regulations are a testimony of the effort being made to increase environmental considerations in forest management, they are too inflexible to promote a proactive and adaptive management approach to deal with the environmental problems faced by forest managers (Charland 1996, Messier and Kneeshaw 1999).

A number of independent voluntary certification programs (FSC, CSA, ISO, etc.) have therefore been developing to ensure that forest management does more than simply meet the minimum conditions set forward in government guidelines (Elliot 1996, Lyke 1996). These programs require forest companies to commit towards continual improvement and, in this respect, they may be more effective, than the slow process of changing regulations, in leading to sustainable forest management. Furthermore, these certification programs operate at a local level, in contrast to the national level CCFM approach (see discussion below), and hence can serve in the evaluation of the sustainability of forest management in a given forest management unit (FMU).

Essentially, there are two certification movements (see Crosley 1996, Evans 1996 for reviews): one developed by the Forest Stewardship Council (FSC) based on fixed environmental standards (Elliot and Hackman 1996) and another, in which we include ISO and the CSA, being developed along environmental management guidelines (Elliot 1996, Lyke 1996, Rotherham 1996). In general, all of these initiatives have well defined guiding principles. The translation, however, of these guiding principles into scientifically sound ecological standards that are both applicable at an operational scale and standardised so as to permit comparison from one region to another is problematic (Rawlinson 1996). Certification is thus, at present, at best an ad hoc approach to determining forest sustainability. Although conceptually interesting, the certification process suffers from a lack of scientific evaluation both at the level of the process itself as well as its implementation (Hughes 1996, Rawlinson 1996).

Furthermore, both government and certification approaches to forest management suffer from being piecemeal approaches, in that a long series of often unconnected indicators is used. It is our hope that the development of a scientific base to indicators can be used to improve current certification programs, at least with respect to the development of ecological indicators.

Whether the goal is certification or simply to improve forest management, forest managers need standardised, accepted indicators of sustainable forest management that are designed for use at the operational scale of a FMU. These indicators should be integrated so that they represent real ecological links found in forest ecosystems. Stakeholder groups, local steering committees, and forest management decision-makers may then decide whether these factors should be objectives or constraints, and how different factors should be weighed in a socially accepted way. For local conditions, some standards may be added, specified or, in some cases, revised; however, a set of transferable minimum standards based on the best scientific knowledge is required for large forest zones (e.g., biomes) to ensure that statements regarding sustainability or the improved management of various resources are both comparable between FMUs and based on ecological principles.

In this regard, knowledge of natural disturbance regimes must therefore be used as a benchmark to determine thresholds and target levels of indicators. The rational behind this is that species are probably best adapted to disturbance characteristics that are close to those that would be generated by natural disturbance regimes for which they have evolved (Franklin 1993, McKenney et al. 1994, Gauthier et al. 1996). It is recognised that this approach may be difficult in landscapes that have long been modified by human activities. Similarly, current knowledge on natural disturbance regimes can be seen as a serious limit to the application of such an approach. However, a purist viewpoint, which states that scientific knowledge is too incomplete on varying and complex systems to provide useful guidelines for SFM, is not helpful. Scientists must participate in the development of ecological standards of SFM, otherwise ecological standards will be defined by others less qualified (Franklin 1995).

In this paper, our objectives are to 1) define the essential attributes of integrated indicators of SFM and 2) show how 
scientific knowledge can and should be incorporated into their development. This paper is directed to both forest practitioners who will implement SFM and to researchers, especially but not uniquely to those working in the Canadian boreal forest, who want to contribute to the development of ecological standards of SFM. For this process to be truly effective, a greater contribution from researchers into the development of scientifically credible operational indicators is essential. Finally, we hope that this paper will not only assist but will also incite forest industries and local stakeholders to use ecological standards in their evaluation of forest management undertaken in a FMU.

\section{Background definitions and concepts}

In the literature on sustainable forest management, different terms have been used to express a variety of similar concepts and ideas. The danger in such cases is that the debate becomes one over tautology and the underlying issues are ignored. The term sustainability is a particularly loaded term whose meaning has been questioned on a number of occasions, (Grumbine 1994, More 1996, Gilmore 1997). In fact, the FSC has removed the use of this term altogether from the discourse regarding its certification process, which are now called certification standards for best forestry practices (FSC 1996). Despite the potential ambiguity associated with the term "sustainable forest management" most of the international initiatives, as well as the CCFM, have retained the term and define it as being the maintenance of a series of criteria and indicators. These criteria determine the large-scale objectives or values that must be maintained. For the purposes of this paper, these criteria define sustainable management.

In broader terms, the concept of sustainability systematically involves both the moral responsibility of the current generation toward its descendants and concerns about the preservation of all services and goods that can be provided by the forest, currently and in the future (Knight, 1996, Thomas and Huke 1996, Toman and Ashton 1996). Even when concentrating solely on ecological elements, as is our goal, our ability to identify the full range of future multiple-use values (see examples in Burton et al. 1992) and to evaluate the long-term impact of current forest practices are obviously limited. Such uncertainty obviously increases the difficulty in making responsible decisions regarding forest resources. We must therefore develop cautious management practices that maintain key features and processes of forest ecosystems.

An ecosystem management approach appears to provide a workable framework (although see Stanley 1995). One of the baseline ideas of ecosystem management is that by maintaining forest conditions within their natural range of variation there is a greater chance to preserve all forest values that are historically present in a natural forest (Hauffler et al. 1996, Thomas and Huke 1996). Knowledge of the historical range of variations of forest conditions is critical in defining management objectives and related threshold levels (Wallin et al. 1994). This also implies that management objectives should be formulated in terms of a range of conditions to be respected instead of being viewed as a single, static target (Bunnell 1997). For sustainable management to be functional it must be viewed as a continuous and ongoing process rather than as and in itself.

\section{Conflicts between scales of assessment}

One of the potential problems regarding the currently proposed certification schemes is that many of the decisions concerning the development of indicators are local in scope. This makes comparisons between several different forest management areas difficult or impossible. In contrast, the CCFM (1997) has developed criteria and indicators attesting to the state of Canadian forests at a national level where many indicators are not specific to forest management activities. For example, counts of the number of forest-dependant species that are classified as rare, endangered or threatened may be useful at a national level in reflecting the overall effects of country-wide forest policy but they are inappropriate at a management unit level. Although such species must be considered and protected within management areas, it is improbable that lists of their presence will reflect the sustainability of local practices.

From a forest manager's perspective, an approach towards SFM should not add extra management activities to the agenda in order to contribute to national goals but rather should help in identifying both 1) management practices that are detrimental to ecosystem processes or species and 2) ways of modifying these practices to mitigate their impacts on the environment. Contrary to the national level where the approach used to define criteria and indicators (C\&I) is centred on forest values; an evaluation of SFM at a local level should focus on forest conditions over which foresters exercise some control.

Forestry operations, however, affect forest conditions at both stand and landscape scales. Stand level indicators are thus required to monitor stand attributes that concern forest conditions (e.g., size of cutting area, residual stocking) or forest values (e.g., biodiversity, aesthetics, eco-spirituality) for which patterns of variability and scales of measurement are more relevant at the stand level. In the same way, at the landscape level, indicators must again include considerations regarding forest conditions and forest values. These scales are obviously dependent, as management choices retained at the stand level have cumulative effects on forest conditions at the landscape level.

\section{Planning and environmental indicators}

An evaluation of forest management activities shows that there are two distinct stages at which ecological indicators of SFM are needed: the management or planning stage and the environmental monitoring stage. Planning indicators can be defined as indicators that are used to set targets to achieve specified SFM objectives. Planning indicators are thus applicable in defining the overall forest management plan at the landscape level and also in planning silvicultural prescriptions at the stand level. As a follow-up, monitoring or environmental indicators are required to verify whether targets set during the planning stage have been attained and whether their achievement results in the desired forest values. Environmental indicators are thus required in both the short-term (soon after interventions) and in the long-term (after many decades or at the rotation age). An environmental indicator is thus more than simply a one-time assessment of forest resources after harvesting. The development of both planning and environmental indicators is thus required to ensure that forest management is continuously improving and moving towards sustainability. This distinction discriminates between our approach and those taken by the various certification programs or by provincial ministries. 
Table 1. Characteristics of good ecological standards of SFM

1) Scientifically sound

2) Operationally feasible

3) Socially responsible and internationally credible

4) Measured following a standard method (Standardisation is also required to ensure consistency in the evaluation of the state of SFM in different FMUs)

5) Easily measurable and cost-effective

6) Easily interpretable and directly linked to environmental changes generated by local management practices (sensitiveness, responsiveness) and relatively insensitive to more global or external sources of variation

7) Integrated (as they are in the real world)

8) Linked to prescriptions

Erdle and Sullivan (1998) also recognise this difference when they make a distinction between forest conditions, that designate the results of forest management, and forest values, that reflect expectations about what should be provided by the forest. Planning and environmental indicators are thus related in an improvement loop in which management practices are continually improved through the achievement of environmental goals. Such an adaptive approach is also crucial to the development of SFM practices. It recognises that although both current technology and current knowledge of ecosystem processes and species requirements are not well enough developed to provide accurate environmental forecasting, they can be used to develop SFM practices through a continuous cycle of redefinition based on new knowledge and/or on the development of new technologies.

What are the attributes of good ecological standards of SFM?

The first step in the process of defining indicators is to determine what qualities or characteristics are necessary to insure that the proposed indicators will actually indicate whether forest management techniques are moving away from, or towards, sustainability (Table 1).

Although many of these points have been treated elsewhere (Bunnell 1997) they are still too often ignored in practice. Most certification processes, for example, ignore (at least partially) the need for scientifically developed indicators, relying on stakeholders' opinions to define good indicators. The involved personnel may include some individuals with scientific backgrounds; however, it is unusual that specialists from all the different SFM criteria would be involved. As for operational feasibility, to date only the Centre for International Forestry Research (CIFOR) has been testing the operational feasibility of many proposed indicators. Of over 200 ecological indicators tested in North America more than 65 were found to be either impractical or unfeasible at an operational level and only 71 were eventually accepted (Woodley et al. 1998).

There is also a clear need to limit the number of indicators to a key group that respond to management activities, although this list can be increased as sampling techniques and infrastructure increase or as new knowledge becomes available. In Ontario, a list of indicator species to be used in the evaluation of forest operations has been developed (McLaren et al. 1998). Although the formulation of criteria for selecting species is clear, rigorous and leads to an exhaustive list of indicators for Ontario's forests ecosystems, the operational feasibility of setting monitoring programs for each indicator at the scale of an FMU can be questioned.

Regional differences and variations in variables exist and must also be considered when evaluating SFM. However, a lack of standardisation will lead to a 1) multiplicity of indicators developed to respond to local conditions but which result in an inconsistent evaluation of SFM in different FMUs (Evans 1996) and 2) to highly prescriptive, local indicators that fail to encompass the variability inherent in natural systems (Rotherham 1996). Achieving standardisation will require the use of standard methods of measurement and interpretation and not the use of national or provincial target levels or the use of a particular species indicator. Standardised indicators may be adapted to local conditions using threshold and target levels specific to each FMU as well as by using equivalent species or guilds of species that are appropriate for each specific region. From an ecosystem management point of view, standardisation means basing management practices on the natural variation following disturbances whereas local thresholds will be defined by the particularities of the disturbance regime in that region. Target levels of indicators should thus be defined by a desirable range of variation that ensures the maintenance of natural processes.

To constitute a tool for improving management practices, an indicator must be coupled with silvicultural prescriptions and/or management guidelines. In a case where a threshold level is not obtained for some environmental indicator, management guidelines must be re-formulated to obtain forest conditions that equal or surpass target levels. There is obviously a gap between forests conditions, induced by management activities, and forest values, that people would like to achieve, that is dynamic through time. Forest values will change constantly as ecological knowledge increases and as public perceptions evolve. Similarly, forest conditions change with advances in technology and due to modifications in regulations governing the use of forest resources (Erdle 1998). The dynamic nature of the relationship between forest conditions and forest values means that the pursuit of SFM should be viewed as a continual process of improvement in management practices.

\section{Examples of Ecological Standards for Forest Management}

The preceding sections have presented a critique of SFM criteria and indicators and our view-point on the required types of indicators as well as the qualities of good indicators. In this section, we present an approach for developing a series of indicators that are functional at an operational level and which will be useful in evaluating generally recognised sustainability criteria. The goal is not to create an exhaustive set of indicators that will unequivocally define sustainability but rather to create a process for the development of meaningful indicators through our examples. These indicators should also be appli- 
cable operationally and serve as an ecological base for discussions on SFM. We have thus chosen to limit ourselves to habitat and wildlife biodiversity, forest regeneration, soil productivity, and aquatic resources.

The proposed indicators are based on current scientific research developed to increase our understanding of forest ecosystems and which can thus be applied for use in manipulations of this resource. A more detailed discussion on the development and the application of each individual indicator will be found in follow-up papers.

\section{A. Biodiversity}

An age structure and stand composition planning indicator

Age structure and stand composition of forest mosaics are clearly identified as indicators of SFM in CCMF documents. Maintaining forest mosaic diversity (age-class distribution and habitat types) in managed systems similar to those observed in natural landscape is often proposed as a coarse filter strategy to minimise the risk of losing important components of biodiversity (Hunter 1990, Seymour and Hunter 1993). The current stand composition of a natural forested landscape reflects the response of forest cover to interactions between physical determinism (climate, topography, surficial geology, etc.) and the disturbance regime associated with each region. Although topography and surface deposits have been relatively stable since the end of the last glaciation, climate and disturbance regimes have experienced temporal variability during this same period (Bergeron et al. 1998, Johnson 1992). Therefore, the development of a coarse-filter approach in a managed landscape requires a knowledge of the historical range of variation of disturbance regimes and its relationship to forest composition features.

In order to determine thresholds and target levels for a region, we propose a two-step approach. In the first step, the natural variability in age-class distribution both in time and space needs to be analysed at spatial scales relevant to the operational scale of a FMU. In the second step, the defined age-class distribution must be translated into an expected distribution of stand composition.

Up to now, scientists have worked within the framework provided by exponential and related models to predict the average age-class distribution of stands from knowledge of a region's fire cycle. Using this framework, Bergeron et al. (1999) have suggested target levels for the maintenance of broad ageclasses in FMAs in relation to the fire cycle of different regions. However, the recent results of Boychuk et al. (1997) indicate that although these exponential models can give insights into the average age-class structure of a relatively large forest mosaic over time, they provide few details on the variance associated with this average age structure. This variance depends on the extent of the managed area on which the diagnosis is being made and on several parameters of the fire regime other than the length of the fire cycle (such as fire occurrence and fire-size distribution). To define the historical range (or variance) of age-class distributions at the FMU level both empirical data and spatial modelling will eventually be required.

Once the expected age-class distribution and its variability are defined, the next step is to relate it to stand composition or habitat types. This can be achieved by using models of natural forest succession performance on different site types similar to those used by Dansereau and Bergeron (1993), Leduc et al. (1995), Gauthier et al. (1996).

The end product of this effort will be a method that determines historical threshold levels for the age structure and stand types in a particular FMU. In some cases, the current age structure and composition of an FMU may be outside of the range of historical variation and thus beyond the acceptable threshold (this situation may be observed in areas with longer management history, such as in Eastern Canada). In such cases, concerns about the effects of these habitat changes on biodiversity (the coarse filter) should be addressed through more precise field evaluations of the state of biodiversity (see below) and through the development and use of alternative silvicultural practices to rectify the situation (see the regeneration example and concluding remarks). Instead of maintaining the forest mosaic, forest managers may need to practice restoration ecology if society requires that the system be returned to a state within its historical range.

\section{Monitoring biological diversity at the landscape level}

An important assumption underlying the management of forest landscapes with appropriate age-class distribution and stand types is that this maintenance of the forest mosaic will provide adequate conditions for all species. Species diversity will be sustained as a result of providing conditions that maintain ecosystem diversity. This assumption must, however, be verified. Environmental indicators of species diversity are thus required to verify whether planning indicators used in the management plan have been successful in achieving their goals once applied in the field.

Even though species diversity implies all living organisms in a given ecosystem, the state of biological diversity cannot be assessed with a species-by-species approach for all organisms living in a forest ecosystem (Franklin 1993). For practical reasons, we must focus on components of species diversity (1) that are likely to respond strongly and quickly to changes in forest landscapes both at the stand and landscape levels, (2) that simultaneously occur in a large number of species, (3) that are relatively easy to survey if we want to monitor forest ecosystem health with regard to biological diversity, (4) that can be surveyed at low cost, and (5) for which we have knowledge of their ecology. Songbirds represent such a key component, even though most species are migratory (Niemi et al. 1998) and population trends may be influenced by factors other than those occurring in the breeding grounds. A considerable body of literature exists to show that songbirds respond to habitat changes in their breeding grounds (Robbins et al. 1989, Askins et al. 1990, Andren 1994, McGarigal and McComb 1995, Robinson et al. 1995). They are also strongly influenced by changes in the structure and composition of the forest cover that occur at different spatial scales (Helle and Järvinen 1986, Angelstam 1990, McGarigal and McComb 1995, Robinson et al. 1995, Edenius and Elmberg 1996, Drapeau et al. in press). For example, Drapeau et al. (in press) found that variations in bird community composition determined by the landscape context (forest mosaic) were as important as local habitat conditions (stand level). Songbirds are thus indicators of both the impacts of silvicultural practices at the stand level and the cumulative effects of management practices at the landscape level. Furthermore, songbirds can be monitored with techniques that are easy to use and that allow us to simultaneously census many 
species at a low cost. Although birds are not the most diverse taxonomic group in forest ecosystems (insects or mosses are much more diverse), it is a group for which we have a good knowledge of species' ecological requirements and, hence, for which we can recognise (unlike with insects or mosses) species that are sensitive to forest management practices with a degree of confidence. Finally, being mostly insectivorous, they are an important component of the food web in forest ecosystems (Holmes 1990). Several studies have shown that birds reduce insect densities (Holmes et al. 1979, Altegrim 1989, Crawford and Jennings 1989) and that bird predation of phytophagous insects can even have positive economic benefits on forest productivity (Takekawa and Garton 1984).

A preliminary step in the assessment of the state of species diversity in managed forest landscapes is to define the response of the environmental indicator (songbirds) to desired thresholds and target levels of the planning indicators (natural variability in stand types and age-class distributions) at spatial scales relevant to the operational scale of a FMU. This can be achieved by linking models of songbird response to landscapescale changes in forest cover to the range of historical variation in forest conditions defined in the preceding section on age structure and stand composition. This coupling of modelling efforts will provide a reference point for further comparisons of the state of biodiversity in FMUs. The second step will be to compare the predicted patterns of target conditions with the observed patterns in managed forests. This should be done both with empirical data from precise field investigations of the state of the avifauna at the scale of FMUs and modelling efforts where projections about landscape scale changes of forest cover and its effects on songbirds will be examined under different scenarios of timber harvesting.

This approach is somewhat different than what is usually proposed with lists of indicator species (McLaren et al. 1998). Here the emphasis is shifted from species to an ecosystems approach. Hence, the primary role of species diversity and its indicator (songbirds) is to assess whether or not the forest in a FMU is within or approaching the desired target conditions. In that sense we view the composition of songbird assemblages as a coarse-filter environmental indicator of a coarse-filter management strategy. Note that although the overall avifauna is used as the environmental indicator, this approach is concerned with species since it is based on single-species models of songbird response to landscape and stand-level changes in forest cover. Finally, this approach does not preclude the use of complementary fine-filter approaches to species that require additional management considerations (Block et al. 1995).

\section{B. Forest Regeneration and Stand Dynamics \\ Landscape level planning indicator}

The notion that productivity must be maintained for a site to be sustainable is also the biological criterion that may most concern forest managers, at least with respect to the continued needs for wood products. Our choice of an indicator is based on the assumption that to ensure sustained yield over long periods requires knowledge that will, at an early stage, let us know the future state of forest productivity. This can be obtained from a reliable knowledge of forest regeneration coupled with soils productivity (see the following section). The regeneration indicator is thus the one for which foresters have had the most experience and for which they harbour a great knowledge. However, in the context of SFM, maintaining natural and continuously changing stand structure and composition are considerations that must be added to the goal of producing a productive commercial crop. This indicator should also be considered from the point of view that changes in forest regeneration will eventually have an impact on the forest mosaic composition and thus on biodiversity. Ensuring adequate regeneration of forest stands will also be a necessary prerequisite to maintaining stand resilience and continued stand productivity. To achieve SFM we must ensure that regeneration is sufficient in quantity, quality and of the appropriate type to guarantee the development of stands that are as productive as pre-disturbance stands within a given period of time.

Controlling for future stand composition following harvesting requires an understanding of natural forest dynamics. This consideration links the regeneration indicator to the forest mosaic indicator. However, while the forest mosaic indicator will help to define the range of acceptable forest compositions to be maintained in a managed landscape, it is through an understanding of regeneration dynamics, such as the distinction between the effect of natural disturbances versus harvesting practices, that the long-term impact of forest management activities on the forest mosaic will be made. In fact, it is recognised that harvest activities may transform the composition and structure of some forests mostly by altering regeneration processes (and forest age structures) and by promoting tree species that are better adapted to new conditions generated by cutting disturbance (Sicama 1971, McIntosh 1972, Whitney 1986, Carleton and MacLellan 1994).

The question of scale separates our approach from those being currently employed (Friedman 1999) and as such may require profound changes in forest management practices. Although practices affecting regeneration occur at the stand level, the sustainable regeneration of forests requires consideration of forests at the landscape level. In forests governed by natural disturbance dynamics, regeneration processes change temporally and spatially across the landscape. Planning for forest regeneration must thus also occur at the landscape level using the assumption that individual stands may differ in composition, structure and biomass production through time, but that across the forest land base these should remain constant or change slowly. Rules, currently in place in many jurisdictions, that require harvested stands to be regenerated to a composition and stocking (as a surrogate for future volume production) that is similar to the original stand may actually run counter to natural dynamics in which individual stands evolve.

Successional processes and stand development processes must therefore be acknowledged. On a given site type (defined by soils indicators), open stands may have a greater abundance and stocking than closed stands and investments may be more wisely used to improve the regeneration norms of such a stand well beyond provincial norms than to struggle to attain an arbitrary minimum threshold (e.g., 60\%) for other more poorly stocked stands (as is the current practice). Similarly, taking advantage of abundant advance regeneration of tolerant species under an intolerant overstory, or planting or coppicing intolerants in a stand formerly dominated by tolerant species but with sparse advance regeneration should not be considered to be stand conversion, as current rules in many jurisdictions suggest, if relative proportions are maintained for each site type across the land base (as determined by the forest mosa- 
ic indicator). Failure to reach regeneration objectives at the stand level can be more easily corrected and at a much lower cost at the landscape level.

A number of approaches are possible to achieve this goal. The first is a heuristic or ecosystem management approach in which natural ecosystem dynamics are used to suggest alternatives or complementary practices to current practices (see example in Bergeron et al. 1999). The second is based on the modelling of regeneration dynamics to allow for silvicultural gaming (evaluations of the effects of different silvicultural scenarios on regeneration dynamics compared to those following natural disturbances using computer simulations e.g., FORECAST, SORTIE/Bc and SORTIE-Boreal, FORSKA, ZELIG, etc.). Mathematical equations based on ecological knowledge of regeneration dynamics have also been developed for use by foresters to predict the success of alternatives to cut and plant operations (Greene et al. 2000). Greater use of such methods in developing and evaluating alternative silvicultural systems will begin to replace more empirical methods in which the characteristics of different stages of stand development are identified in forest regeneration research (e.g., the abundance and stocking of germinants at time of establishment, the seedling stage, the sapling stage, etc.) and summarised into field guides for use in avoiding or rectifying potential problems. However, only an empirical approach can be used for environmental monitoring.

\section{Environmental regeneration indicator}

The effectiveness of monitoring the regeneration planning process requires well defined objectives for each stand as part of the overall landscape during the planning stage. Judgements on regeneration success should always be based on initial planning goals and objectives for each stand to meet landscape level objectives.

Monitoring the relative success of the regeneration in each stand will be based on determining whether regeneration abundance (or stocking) is sufficient and whether this regeneration is growing acceptably. Such monitoring is in place in many jurisdictions, at least with respect to a short-term, postharvest evaluation. The quantity and quality of seedlings by species and their growth and survival potential after disturbance is a simple but effective measure of the regeneration potential. The quality of the regeneration may be judged by factors such as the stocking and spatial distribution of seedlings as well as seedling size, growth rate and crown form (whether injured or not, live crown ratio, etc.). Species-specific indicators of vigour have been developed for most boreal tree species. In many cases, stocking is more important in determining the future yield of a stand than is the quantity of seedlings (and at least one of these is usually evaluated). Low stocking will lead to stands with low yield, as effective growing area is not being used. An understanding of the spatial distribution (e.g., clumped vs. uniform but wide spacing) of seedlings will, however, be required for curative measures. Density (e.g., high densities will slow down stand growth and a curative measure would be to thin the stands) and species specific growth for different sites will, however, give an idea of the time required to achieve a target stand. In the long-term, it is monitoring at rotation age that will verify if initial composition, structure and volume goals are attained. It is thus imperative that the use of post-harvest stocking be evaluated by determining the relationships between seedling stocking and subsequent merchantable stem stocking and volume for each species on different site types (Doucet 1991, Pominville and Doucet 1993). A strong link is therefore necessary with soil productivity indicators.

\section{Ecological Indicators for Soil Productivity Planning indicators: both direct and indirect for soil condition}

The general objective of this indicator is to insure the maintenance of soil properties that would allow the resilience of forest productivity following disturbance. It is therefore important to address the question of whether the indicators should be soil or plant properties. A comparison of wood volume for successive rotations is considered to be the ultimate measure of long term productivity by most forest researchers (Morris and Miller 1994). However, the use of a plant bioassay to monitor forest soil productivity has been criticised by Burger (1996) who pointed out that productivity is the result of several processes, including soil, genotype, plant competition, pests, and other environmental factors, and that monitoring of changes in critical soil properties may be the only sure way to monitor forest soil quality, productivity and sustainability in the long run. The interacting influence of all the factors contributing to plant productivity may, in fact, suggest that some practices are beneficial while key soil properties are still being degraded. Such cases have been observed in agriculture as yields during most of this century have increased despite the fact that soil quality was deteriorating, leading eventually to a levelling off or to a yield decline (Burger 1996). The definition of soil quality is evolving rapidly in agriculture as physical, chemical and biological indices of soil quality are being implemented (Doran et al. 1994). We agree with Burger (1996) that forest soil quality should be monitored with soil parameters. However, to make this possible for boreal forests it must be recognised that forest soil properties are highly variable over short distances and a high number of samples are required to monitor a single site. For example, a slight change in slope can affect drainage and have a strong effect on important properties such as soil organic matter content. Unlike most agricultural soils, forest soils, and especially soils of the boreal forest, undergo important changes with time since disturbance. It is easier to have an indicator in agricultural soils where soil properties should, for a given site, vary only with seasonal changes and not between years. Year to year variation and changes with stand age are an intrinsic property of forest soils (Paré et al. 1993).

For these reasons, a good indicator of soil quality should be site-specific. The extensive management that is usually found in the boreal forest and the poor knowledge of soil variability makes this task difficult. Properties such as soil reserves of organic matter, the $\mathrm{C}$ to $\mathrm{N}$ ratio of soil organic matter, and the foliar nutrient composition would be good indicators of soil fertility; however, we lack information on the variability of these factors and on their relationships to permanent soil properties to use them at the moment. While waiting for this knowledge to be developed, a heuristic approach may be to identify the most stressful practices and the most susceptible sites.

Physical damages to the soil, such as erosion, mass wasting, compaction and rutting, are largely avoidable (Weetman 1998) and may be used to formulate numerous planning indicators. Careful planning of operations, such as winter harvesting, 
with an identification of fragile sites and tight inspection can limit these problems. Indicators of severe physical disturbance to the soil are currently being implemented in Québec (L'Écuyer and Jetté 1998).

Monitoring of the mid- to long-term impact of forest operations on the soil nutrient-providing capacity is, however, rarely undertaken. While most forests are deficient in nitrogen or phosphorus, nutrient budget analyses indicate that calcium is the nutrient most significantly depleted by harvesting (Johnson 1994). The rationale is that calcium and other cations are little affected by natural disturbance such as fire or insect outbreaks, while these elements are extracted from the site with the harvested biomass. The main source of these elements is the weathering of soil minerals. The amount of elements provided by this flux is dependant on soil mineralogy, soil temperature, soil water content and soil acidity. It is thus possible to produce field guides that roughly rank soils by their cation-providing capacity based on soil texture, depth, stoniness and drainage. Simulation models, such as PROFILE (Sverdrup and Warfinge 1992) can also provide estimates of mineral weathering for specific site types but these estimates have not been validated. These fluxes can then be compared with estimates of nutrient outputs in harvested products, which are dependant on tree species, method of harvesting (whole-tree vs. stem-only), stand site index, density and stand age. A tool estimating the exportation of nutrients in relation to these parameters is being completed (Paré et al. 1999). The comparison of outputs in wood products with inputs from mineral weathering can determine situations that are likely to be most stressful to the soil nutrient budgets. This knowledge can help managers to direct stem-only harvesting to the most susceptible sites and to favour the establishment of the most demanding tree species on the richest sites. Initial guides to maintaining soil fertility based on the harvesting system (whole-tree or stemonly), soil deposit, tree species and rotation age have recently been developed for boreal tree species (Paré 2000).

\section{Monitoring soil condition}

Monitoring changes in soil nutrient-providing capacity can also be evaluated indirectly by estimating vegetation recovery. This could be done by aerial photography or by evaluating vegetation colonisation for a given distance (e.g., $30 \mathrm{~m}$ ) along roadsides. The recovery of the Leaf Area Index (projection of the surface of leaf per area $-\mathrm{m}^{2} / \mathrm{m}^{2}$ ) as well as its distribution (frequency and importance of gaps) would allow a gross estimation of the degree of disruption of nutrient cycling. An important link will thus be made here between the soil productivity indicator and the regeneration/stand dynamics indicators. The importance of groups of vegetation known to be detrimental to soil fertility, such as ericaceous plants and sphagnum mosses, or of plants known to have a beneficial effects on soils, such as deciduous plants could also be evaluated and compared to what is observed on sites affected by natural disturbances (Paré 2000).

\section{Aquatic Resources}

There are over one million lakes and countless streams and rivers on the Canadian Shield, where they typically account for $10-15 \%$ of the landscape, and where they represent an important economical, recreational and subsistence resource. For these reasons, the protection of lakes and running waters must be an integral part of future strategies for sustainable forest development. Basic sustainability criteria and indicators applicable to these systems must therefore address the preservation of functional and structural aquatic ecosystem integrity and the preservation of natural resources associated with fresh waters (fisheries, drinking water supply, recreation).

Preserving aquatic ecosystem integrity requires the maintenance of key properties within their natural range of variation as determined by their response following natural disturbances. These properties can be functional, such as biological productivity, decomposition and nutrient cycling, or structural, such as biodiversity and community composition. Structural properties generally constitute the most sensitive indicators of ecosystem stress. Evaluating structural (and functional) ecosystem properties is, however, particularly time-consuming and expensive. For this reason, practical indicators of aquatic ecosystem integrity should be based on easily measurable and manageable biophysical factors known to affect the integrity and the economic value of fresh water ecosystems. These factors can be divided into three broad classes: Chemical (toxic contaminants, nutrient supply, organic carbon), Physical (temperature, light, erosion) and Biotic (density of top predators such as salmonids, pike, and walleye).

Each of these three classes also includes key properties that can be used for environmental indicators because 1) they play central roles in determining ecosystem structure and function, 2) they can be easily measured or sampled in the field, and 3) they are known to be influenced by forestry practices. In most cases, research has already established quantitative relationships linking these indicators to forestry practices. An understanding of the effects of different forestry practices on different watershed parameters and the temporal variation in these parameters following natural disturbances such as fire can thus be used to develop management indicators.

\section{Planning indicators for aquatic resources}

Forest harvesting causes temporary but major disruptions to soil nutrient cycles and to hillslope hydrology. In turn, these effects produce significant changes to the chemical composition and the quality of surface waters. In boreal Shield lakes, the factors that are primarily affected, e.g., dissolved organic carbon (DOC) and colour, are empirically related to the drainage ratio (the size of the lake vs. the size of the watershed), the topography and the proportion of the watershed that is harvested (Carignan et al. 1999). A knowledge of the first two variables can thus be used to plan the proportion of the watershed that can be cut without causing deleterious effects (those effects that exceed the natural temporal variation). Currently, such guidelines have been developed for a region in central Québec (Carignan et al. 2000). These same planning indicators should also be effective in limiting increases in mercury inputs.

In streams, however, temperature is strongly influenced by the degree of canopy closure above streams and thus by the presence of fringing buffer strips. Furthermore, excessive erosion in the watershed and the transport of eroded material into streams and lakes can cause a deterioration of fish spawning grounds and recruitment failures, as reported by Magnan and St-Onge (1999) and others. Excessive loading of suspended material in streams and lakes can be managed by planning sufficient buffer strips, adequate culvert installations, and minimal soil disturbance on steep slopes. Although residual 
buffer strips are an established practice in forestry, their resistance to blowdown and long-term effectiveness depend on prescribed width, species, stand age and vegetation type, which can vary considerably between regions.

Aquatic biodiversity will be affected by changes in physical and chemical parameters following modifications to the forests in a watershed. Across the landscape aquatic biotic components should not be adversely affected if changes are maintained within the limits occurring following natural disturbances in watersheds. As with other components of biodiversity, road access (for which there is no natural analogue) to previously inaccessible areas should be carefully planned, as it may lead to pressure on some species (e.g., through overexploitation of fish stocks).

\section{Environmental indicators of aquatic resources}

Research conducted in boreal Shield lakes (Carignan et al. 1999, Garcia and Carignan 1999) reveals only minor disruptions to aquatic nutrient cycles. On the other hand, salient effects of clearcuts include increased concentrations of coloured dissolved organic carbon (DOC) and mercury. DOC strongly influences several chemical (e.g., formation of toxic trihalomethanes, related to mercury loading), physical (an increase in surface water temperature, a decrease in thickness of the warm surface layer) and biological (loss of warm water fish habitat due to temperature changes and, possibly, a loss in cold water fish habitat through increased oxygen deficits in deep waters) properties in lakes because it imparts a significant brown staining to the water, thereby reducing photosynthesis and biological productivity.

Chemically, DOC degrades the quality of surface waters as a drinking water source through the formation of toxic trihalomethanes. Excessive toxic methyl-mercury concentrations in game fish is an endemic problem in boreal Shield lakes, where concentrations often exceed the limit $(0.5 \mathrm{mg} / \mathrm{kg})$ recommended for safe human consumption. Research has shown that the problem is exacerbated in lakes draining clearcut watersheds (Garcia and Carignan 1999). Our present knowledge of the biogeochemistry of mercury in the boreal forest indicates that mercury loading in lakes is highly dependent on DOC loading.

Physically, temperature and light penetration (transparency) are two easily measured at low cost physical environmental indicators. In unproductive Shield lakes, coloured DOC produced in the watershed is by far the main factor responsible for underwater light attenuation. Most invertebrate and fish species have well-defined temperature optima, and thus temperature is another obvious environmental indicator. However, in lakes, other conditions being equal, surface water temperatures will largely depend, again, on coloured DOC concentrations. Excessive erosion in the watershed is also a problem (Magnan and St-Onge 1999) and although no easily measured environmental indicators for erosion have been proposed so far, the determination of the concentration of suspended material in streams at peak runoff is a promising tool. Buffer strip persistence, as buffers protect the viability of aquatic habitats, could also be considered during monitoring, at least until the surrounding vegetation has recovered.

Biologically, for fisheries, fish yield statistics appear to be the most straightforward environmental indicator.

\section{Integrating Ecological Standards}

It is our view that the proposed indicators could form a strong base for a truly sustainable forest management program. The interconnectedness between indicators (Fig. 1) also suggests that a failure to achieve the defined goals in any area of concern may have important consequences on other indicators. For example, forest mosaic and regeneration indicators are both linked by evaluating composition at different scales. Similarly, changes in soil productivity may affect stand productivity (even if the target number of stems have successfully regenerated) and also water quality if nutrients or sediments lost from soils are leached into waters. Aquatic and terrestrial biodiversity are both components of overall biodiversity affected by forest management activities (e.g., harvesting and road networks).

This important link between indicators is not often made in most other SFM programs. Instead, indicators are usually developed individually by expert panels. Moving beyond an ecological perspective, similar consequences exist when socioeconomic indicators are also considered (Chapin and Whiteman 1998). Without a strong understanding of ecological functioning and the relationship between different ecological components the long-term sustainability of communities and forestry operations may in themselves be compromised. Until recently, natural resources were only considered from a social, political and economic perspective, with ecosystems themselves being an abundant but hidden backdrop (Shrivastava 1994). An understanding of ecological functioning must, however, form the base of any exercise that is to be truly sustainable with social and economic decisions being made fully conscious of their potential ecological ramifications.

In such an exercise it is important to note that although weights of societal importance may be assigned to different indicators (based on some set of values), the relationship between the indicators themselves can not be compromised. In other words, it is crucial to understand the intensity of the links between different indicators before assigning weights. For example, exportation of nutrients from soil reserves will have a direct impact on nutrient levels in aquatic systems irrespective of the importance values that stakeholders may have arbitrarily assigned to the effects of forestry practices on lakes or soil resources. Furthermore, the complex of indicators used to define sustainability criteria proposed by other groups (CCFM 1997, FSC 1996, CSA 1996, and MNRQ 1999) are mostly based on a static, non-integrated view of forest resources. Although these documents recognise the importance of landscape level decisions, most indicators are based on stand-level observations that are often simply scaled up. Furthermore, for sustainable forest management to occur indicators must be firmly rooted in an understanding of natural processes and management practices for meaningful advances to be made. Friedman's (1999) review of how certification standards compare with respect to regeneration practices provides at least one example of how good intentions may not necessarily maintain a natural composition in our forests. In most of the reviewed standards concerns about the use of artificial regeneration result in the requirement of an overwhelming use of natural regeneration without considering whether regeneration following cutting and natural disturbance are the same. Without an integrated approach to the development of such standards it is also possible that conflicts between standards may arise. An example 


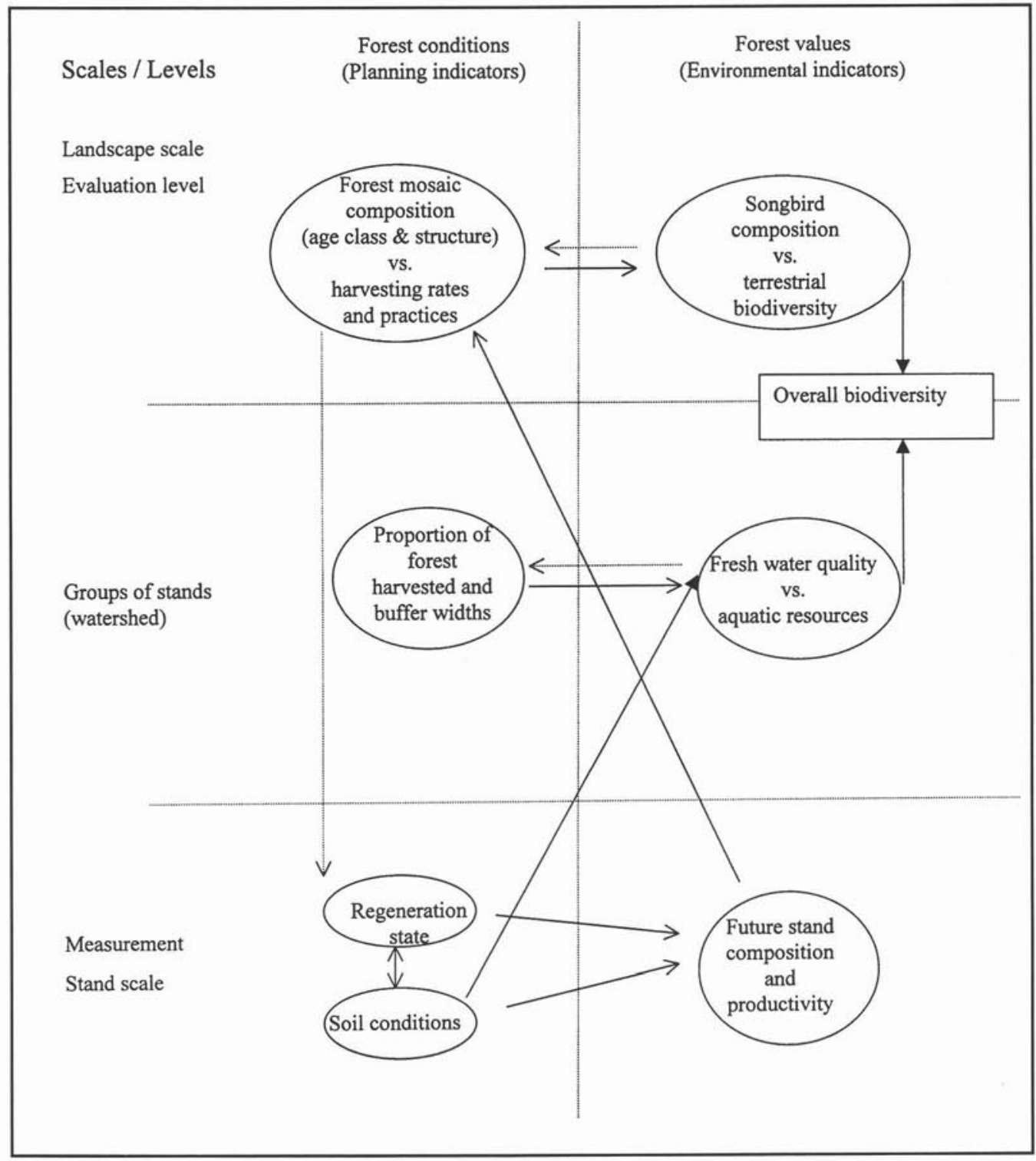

Fig. 1. An example of the types of links occurring between indicators. The solid arrows represent positive feedbacks and the dashed arrows represent negative feedbacks. The forest mosaic composition is used in forest planning to maintain habitat for biodiversity. This can be monitored by following songbird populations. Adjustments to harvesting practice can then be made using knowledge of the ecology of the declined species'. The forest mosaic will also determine the range of stands regenerating to different species, etc. This regeneration state will then lead to a future stand composition (productivity, etc.) which may be different then the planned composition depending on the success in applying the forest plans. Future stand productivity will not only depend on the quantity and quality of the regeneration but also on soil conditions, and any modifications to soil condition (e.g., through leaching or erosion) will affect water conditions.

of a possible conflict, is the desire to manage for large ungulates by increasing edge habitat versus the maintenance of species that require large areas of interior habitat.

Similarly, if biophysical indicators are not well understood there is the chance that they will not be implemented. There is also a risk that if the cost to society is perceived as being too high, the thresholds determined for these indicators will be ignored. The FSC maritime standards (http://www. canadian-forests.com/fsc-standard.html), for example, include a number of standards for which economic costs may be high but for which failure will void certification within a given period of time.

\section{Varying forest management intensity as a tool to maintain ecosystems}

In the literature a number of approaches have been proposed in which a diversity of forest practices would occur across the landscape (Harris 1984, Seymour and Hunter 1993, Binkley 1997, Bergeron et al. 1999, Burton et al. 1999). The standards that we propose would be compatible with these approaches in that an understanding of natural dynamics is proposed to govern forest practices. In this view, temporal and spatial changes in certain attributes are to be expected at the stand level although these will be balanced across both the landscape and longer time horizons. The focus should thus be placed on desired 
outcomes rather then on a series of regulations (Bunnell 1996)

Whether the government or companies are responsible for ensuring SFM (see Côté and Bouthillier 1999 for a discussion) they should be governed not by strict rules but with guidelines that can allow them to be creative and achieve higher levels of sustainability than could ever be accomplished by satisfying the minimum requirements of the law. There should be a real system of rewards and incentives based on sound ecological principles put in place to encourage companies to achieve higher levels of management.

With the inclusion of new considerations about multiple landuse and the maintenance of biodiversity, forest management becomes closer to land management. As the principal user of forest resources and the main agent of change in the forested landscape, forest industries must play a major role in planning the development of forested landscapes or regions. A fundamental shift in our thinking about forest resource management needs to occur in which ecosystem resilience is considered in economic and social decision-making processes (Chapin and Whiteman 1998) and also in which conservationists consider humans as part of the ecosystem (Bunnel 1997).

\section{Conclusions}

Government agencies and other bodies have been trying to develop systems of regulations, standards or indicators to judge and govern forest management. These various proposals all have the objective of ensuring the sustainability of all facets of the forest resource. Despite the considerable effort put into these systems a number of drawbacks are inherent in them all. Thus, although they may improve the current state of forest management, further steps are needed to ultimately ensure sustainability.

We propose an approach in which ecological principles grounded in scientific knowledge form the base on which discussion on the use of forest resources occurs. In this way social and economic issues can be discussed with the most up-to-date knowledge of the capacity of forest ecosystems to support multiple uses for many generation of users.

Our approach is different from most of the others, not only in its strong foundation on scientific knowledge of ecosystem functioning, but also in the fact that the indicators are strongly interrelated as in real ecosystems. We view the ecosystem as a whole and not as an assemblage of different important parts that are not connected and which may at times be in conflict. Our approach to developing indicators is based on an understanding of the natural variability in ecosystems and how the different components react together. Since the invention of the assembly line we have become accustomed to working on small parts of a problem and to seeing problems broken down into various components, but to successfully manage ecosystems we will have to learn to manage the forest as a whole.

\section{Acknowledgements}

This research has been supported by the Sustainable Forest Management Network and Cartons St-Laurent. Financial support of the first author from the Fondation UQAM through the Societé St-Jean Baptiste and from the National Science and Engineering Council of Canada is also greatly appreciated. We would also like to thank Marie-Josée Fortin, Benoit St-Onge, the Chaire Industrielle CRSNG-UQAT-UQAM en Aménagement Forestier Durable and two anonymous reviewers for their comments on this manuscript.

\section{References}

Andren, H. 1994. Effects of habitat fragmentation on birds and mammals in landscapes with different proportions of suitable habitat: a review. Oikos 71: 355-366.

Anglestam, P. 1990. Factors determining the composition and persistence of local woodpecker assemblages in taiga forest in Sweden - a case for landscape ecological studies. In A. Carson, and G. Aulén (eds.). Conservation and management of woodpecker populations. pp. 147-164 Swedish Univ. Agr. Sci., Dept. Wildl. Ecolol. Uppsala, Report 17. Uppsala.

Askins, R.A., J.F. Lynch and R. Greenberg. 1990. Population declines in migratory birds in eastern North America. Current Ornithology 7: $1-56$.

Atlegrim, O. 1989. Exclusion of birds from bilberry stands: impact on insect larval density and damage to the bilberry. Oecologia 79: 136-139.

Bergeron, Y., B. Harvey, A. Leduc and S. Gauthier. 1999. Silvicultural practices and forest management strategies that emulate natural disturbances. For. Chron. 75: 49-54.

Bergeron, Y., P.J.H. Richard, C. Carcaillet, M. Flannigan, S. Gauthier and Y. Prairie, 1998. Variability in Holocene fire frequency and forest composition in Canadian southeastern boreal forest: a challenge for sustainable forest management. Conservation Ecology 2: art. 6.

Binkley, C.S. 1997. Preserving nature through intensive plantation forestry: The case for forestland allocation with illustrations from British Columbia. 73: 553-559.

Block, W. M., D. M. Finch and L. A. Brennan. 1995. Single species versus multiple-species approaches for management. In T. E. Martin and D. M. Finch (eds.). Ecology and Management of Neotropical migratory birds, A Synthesis and Review of Critical Issues. pp. 461-476. Oxford University Press. New York, New York.

Boychuck, D., A.H. Perrera, M.T. Mikaelian, D.L. Martell and C. Li. 1997. Modelling the effect of spatial scales and correlated fire disturbances on forest age distribution. Ecol. Modelling 95: 145-164. Brunson, M. 1996. Integrating human habitat requirements into ecosystem management strategies: A case study. Nat. Areas J. 16: 100-107. Bunnell, F.L. 1996. Toto, this isn't Kansas: Changes in integrated forest management. Proceedings from the Integrated forest management workshop, Sussex, New Brunswick, October 3-5, 1994.

Bunnell, F. 1997. Operational criteria for sustainable forestry: focusing on the essence. For. Chron. 73: 679-684.

Burger, J. A. 1996. Limitations of bioassays for monitoring forest soil productivity: Rationale and example. Soil Sci. Soc. Am. J. 60: 1674-1678.

Burton, P.J., A.C. Balisky, L.P. Coward, S.G. Cumming and D.D. Kneeshaw. 1992. The value of managing for biodiversity. Forestry Chronicle 68: 225-237.

Burton, P.J., D.D. Kneeshaw and D.K. Coates. 1999. Managing forest harvesting to maintain old growth in boreal and sub-boreal forests. For. Chron. 75: 623-631.

Canadian Council of Forest Ministers (CCFM). 1997. Criteria and indicators of sustainable forest management in Canada. Technical Report. Natural Resources Canada, Canadian Forest Service. Ottawa, Ontario. 137 p.

Canadian Standards Association (CSA). 1996. A sustainable forest management system. Z808 and Z809. Canadian Standards Association, Toronto,

Carignan, R., P. Darcy, B. Pinel-Allouol, J. Kalff, D. Planas and P. Magnan. 1999. Comparative impacts of fire and forest harvesting on water quality in boreal shield lakes. Proc. Sustainable Forest Management Network Conference, Science and practice: Sustaining the boreal forest. pp. 121-126. Edmonton 14-17 February, 1999. 
Carignan, R.P., D. Planas and P. Magnan. 2000. Atténuation des impacts de la coupe forestière sur les lacs de la Haute-Mauricie. In D.D. Kneeshaw (eds.). Towards an ecological forestry: A proposition for indicators of SFM inspired by natural disturbances. pp. 21-28. SFMN Paper.

Carleton, T.J. and P. MacLellan. 1994. Woody vegetation responses to fire versus clearcut logging. Ecoscience 1: 141-152.

Chapin, F.S. and G. Whiteman. 1998. Sustainable development of the boreal forest: Interaction of ecological, social and business feedbacks. Conservation Ecology 2 (2): 12, 15 p.

Charland, J.W. 1996. The 'Problem-Isolation' paradigm. J. For. 94: 6-9.

Côté, M.A. and L. Bouthillier. 1999. Analysis of the relationship among stakeholders affected by sustainable forest management and forest certification. For. Chron. 75: 961-966.

Crawford, H.S., and D.T. Jennings. 1989. Predation by birds on spruce budworm Choristoneura fumiferana: functional, numerical, and total responses. Ecology 70: 152-163.

Crossley, R. 1996. A review of global forest management certification intiatives: political and institutional aspects. Proc. Conf. Economic, social and political issues in certification of forest management. 12-16 May, 1996. Kuala Lumpur, Malaysia

Dansereau, P. and Y. Bergeron. 1993. Fire history in the southern part of the boreal forest of northwestern Quebec. Canadian Journal of Forestry Research 23: 25-32.

Doran, J.S., D.C. Coleman, D.F. Bezdicek and B.A. Stewart. 1994. Defining soil quality for a sustainable environment. SSSA special publication number 35. Madison, WI. 245 p.

Doucet, R., 1991. The influence of stocking of regeneration on the yield of naturally regenerated jack pine and black spruce stands. In C.M. Simpson (ed.). Proc. Conference on natural regeneration management, Fredericton, N.B., 27-28 March 1990. pp. 181-192. Forêts Canada, Centre de For. des Maritimes.

Drapeau, P., A. Leduc, J.-F. Giroux, J.-P. L. Savard, Y. Bergeron and W. L. Vickery. Landscape-scale disturbances and changes in bird communities of eastern North American boreal mixed-wood forests. Ecology. In press.

Edenius, L. and J. Elmberg. 1996. Landscape level effects of modern forestry on bird communities in North Swedish boreal forests. Landscape Ecology 11: 325-338.

Elliot, C. 1996. Forest management certification: ISO, FSC and CSA: What's going on. Taiga News 19.

Elliot, C. and A. Hackman. 1996. Current issues in forest certification in Canada. World Wildlife Fund, Toronto, ON.

Erdle, T. 1998. Progress towards sustainable forest management: Insight from the New Brunswick experience. For. Chron. 74: 378-384.

Erdle, T. and M. Sullivan. 1998. Forest management design for contemporary forestry. For. Chron. 74: 78-82.

Evans, B. 1996. Technical and Scientific Elements of Forest Management Certification Programs. Proc. Conf. Economic, social and political issues in certification of forest management. 12-16 May, 1996. Kuala Lumpur, Malaysia.

Franklin, J.F. 1993. Preserving biodiversity: species, ecosystems or landscapes? Ecological applications 3: 202-205.

Franklin, J.F. 1995. Scientists in wonderland: experiences in development of forestry policy. Bioscience Supplement: 74-78.

Friedman, S.T. 1999. Forest regeneration practices - How regional certification standards compare. J. For. 97: 23-32.

Forest Stewardship Council (FSC). 1996. Principles and criteria for forest stewardship. FSC Report. Mexico City.

Garcia, E. and R. Carignan. 1999. Impact of wildfire and clear-cutting in the boreal forest on methyl mercury in zooplankton. Can. J. Fish. Aquat. Sci. 56: 339-345.

Gauthier, S., A. Leduc and Y. Bergeron. 1996. Forest dynamics modeling under a natural fire cycle: A tool to define natural mosaic diversity in forest management. Environ. Monitoring Asess. 39: 417-434.
Gilmore, D.W. 1997. Ecosystem management - A needs driven, resource-use philosophy. For. Chron. 73: 560-564.

Greene, D., D.D. Kneeshaw, C. Messier, V. Lieffers, R. Doucet and G. Grover. 2000. Silvicultural Alternatives to Clearcutting and Planting in Southern Boreal Mixedwood Stands (aspen/white spruce/balsam fir). SFMN White Paper, Edmonton, Alberta.

Grumbine, R.E. 1994. What is ecosystem management? Conservation biol. 8: 27-38.

Harris, L.D. 1984. The fragmented forest: island biogeography theory and the preservation of biotic diversity. University of Chicago Press.

Hauffler, J.B., C.A. Mehl and G.J. Roloff. 1996. Using a coarsefilter approach with species assessment for ecosystem management. Wildl. Soc. Bull. 24: 200-208.

Helle, P., and O. Järvinen. 1986. Population trends of North Finnish land birds in relation to their habitat selection and changes in forest structure. Oikos 46: 107-115.

Holmes, R.T. 1990. Ecological and evolutionary impacts of bird predation on forest insects: an overview. Studies in Avian Biology 13: 6-13.

Holmes, R.T., J.C. Schultz and P. Nothnagle. 1979. Bird predation on forest insects: an exclosure experiment. Science 206:462-463. Hughes, R. 1996. Sustainable forest management certification: an auditor's perspective. For. Chron. 72: 265-267.

Hunter, M.L., Jr. 1990. Wildlife, forests and forestry. Principles for managing forests for biodiversity. Prentice Hall.

Johnson, E.A. 1992. Fire and vegetation dynamics: studies form the North American boreal forest. Cambridge studies of ecology. Cambridge University Press. $129 \mathrm{p}$.

Johnson, D.W. 1994. Reasons for concern over impacts of harvesting. In W.J. Dyck, D.W. Cole and N.B. Comerford (eds.). Impacts of forest harvesting on long-term site productivity. pp.1-12. Chapman and Hall.

Kimmins, J.P. 1992. Balancing act: environmental issues in forestry. UBC Press, Vancouver, B.C. 244 p.

Knight, R.L. 1996. Aldo Leopold, the land ethic, and ecosystem management. J. Wildl. Manage. 60: 471-474.

L'Écuyer, H. and J.P. Jetté. 1998. Indicateur des perturbations physiques du sol. Note technique MRNQ.

Leduc, A., S. Gauthier Y. Bergeron, Y. 1995. Prévision de la composition d'une mosaïque forestière naturelle soumise à un régime de feu: proposition d'un modèle empirique pour le nord-ouest du Québec. In Domon and Farlardeau (eds.). Actes du 4e Congrès de la Société Canadienne d'Écologie et d'Aménagement du Paysage. pp. 197-203. Polyscience Pub., Morin-Height.

Lyke, J. 1996. Forest product certification revisited: an update. J. Forestry 94: 16-20.

Magnan, P. and I. St-Onge. 1999. Impact of logging and natural fires on fish communities of Laurentian shield lakes. In Conf. Proc. Sustainable Forest management Network Conference, Science and practice: Sustaining the boreal forest, Edmonton, 14-17 February 1999. pp. 150-154.

McGarigal, K. and W.C. McComb. 1995. Relationships between landscape structure and breeding birds in the Oregon coast range. Ecological Monographs 65:235-260.

McIntosh, R.P. 1972. Forest of the Catskill Mountains, New York. Ecol. Monogr. 42: 142-161.

McKenney, D.W., R.A. Sims, F.E. Soulé, B.G. Mackey and K.L. Campbell (eds.). 1994. Towards a set of biodiversity indicators for Canadian Forests: Proceedings of a forest biodiversity indicators workshop. Sault Ste. Marie, Ontario, Nov. 29-Dec.1, 1993. 133 p.

McLaren, M.A., I.D. Thompson and J.A. Baker. 1998. Selection of vertebrate wildlife indicators for monitoring sustainable forest management in Ontario. For. Chron. 74: 241-248.

Messier, C. and D.D. Kneeshaw. 1999. Thinking and acting differently for a sustainable management of the boreal forest. For. Chron. 75: 929-938. 
Ministère des ressouces naturelles du Québec (MRNQ). 1999. Critères et indicateurs de développement forestier durable: Plan de mise en oeuvre. Ministère des Ressources naturelles du Québec, Direction de l'environnement forestier. Quebec City. 118 p.

More, T.A. 1996. Forestry's fuzzy concepts - An examination of ecosystem management. J. For. 94: 19-23.

Morris, L.A. and R.E. Miller. 1994. Evidence for long-term productivity changes as provided by field trials. In W.J. Dyck, D.W. Cole and N.B. Comerford (eds.). Impacts of forest harvesting on long-term site productivity. pp. 41-80. Chapman and Hall, N.Y.

Niemi, G., J. Hanowski, P. Helle, R. Howe, M. Mönkkönen, L. Venier and D. Welsh. 1998. Ecological sustainability of birds in boreal forests. Conservation Ecology [online] 2(2): 17. Available from the Internet. URL: http://www.consecol.org/vol2/iss2/art17

Paré, D. 2000. Maintenir la fertilité des sols de la forêt boréale. In D.D. Kneeshaw, C. Messier, J-P Ricard, A. Leduc, P. Drapeau, R. Carignan, D. Paré, S. Gauthier, R. Doucet and D. Greene. Towards an ecological forestry: A proposal for indicators of SFM inspired by natural disturbances. pp. 29-35. SFMN Paper.

Paré, D., Y. Bergeron and C. Camiré. 1993. Changes in the forest- floor of Canadian southern boreal forest after disturbance. Journal of Vegetation Science 4: 811-818.

Paré, D., P. Rochon and B. Hamel. 1999. Predicting the effect of forest harvesting on soil nutrient availability in the boreal forest. Project Report 1999-33. Sustainable Forest Management Network, Univ. of Alberta, Edmonton. 16 p.

Perez, L.M. 1996. Analysis of social elements in forestry certification. Proc. Conf. Economic, social and political issues in certification of forest management. 12-16 May, 1996. Kuala Lumpur, Malaysia.

Pominville, P. and R. Doucet, 1993. Coefficients de distribution de la régénération nécessaires au maintien de la production des peuplements de pin gris, d'épinette noire et de sapin baumier. Dir. de la rech., Note de rech. for. $\mathrm{n}^{\circ} 48.15 \mathrm{p}$.

Rawlinson, E. 1996. CSA sustainable forest management systems: getting ready. For. Chron. 72: 261-264.

Robbins, C. S., D.K. Dawson and B.A. Dowell. 1989. Habitat area requirements of breeding forest birds of the middle Atlantic states. Wildlife Monographs 103: 1-34.

Robinson, S. K., F. R. Thompson, T. M. Donovan, D. R. Whitehead and J. Faaborg. 1995. Regional forest fragmentation and the nesting success of Migratory birds. Science 267:1987-1990.
Rotherham, T. 1996. Forest management certification - Objectives, international background and the Canadian program. For. Chron. 72: $247-252$.

Seymour, R.S. and M.L. Hunter, Jr. 1993. New forestry in Eastern Spruce-Fir forests: Principles and applications to Maine. Maine Agricultural Experiment Station Miscellaneous Publication 716.

Schindler, B. 1998. Does the public have a role in forest management? Canadian and U.S. perspectives. For. Chron. 74: 700-702.

Schindler, B., B. Steel and P. List. 1996. Public judgements of adaptive management. J. For. 94: 4-12.

Shrivastava, P. 1994. CASTRATED environment: Greening organizational studies. Organization Studies 15: 705-726.

Stanley, T.R., Jr. 1995. Ecosystem management and the arrogance of humanism. Conservation Biology: 252-262.

Sicama, T.G. 1971. Presettlement and present forest vegetation in northern Vermont with special reference to Chittenden County. Amer. Mid. Nat. 85: 153-172.

Sverdrup, H. and P. Warfinge. 1992. Calculating critical loads of acid deposition with PROFILE-A steady-state soil chemistry model. Water, Air and Soil Pollution, 63: 119-143.

Takekawa, J.Y. and E.O. Garton. 1984. How much is an Evening Grosbeak worth? J. For. 82: 426-428.

Thomas, J.W. and S. Huke. 1996. The forest service approach to healthy ecosystems. J. For. 94: 14-18.

Toman, M.A. and P. M.S. Ahston. 1996. Sustainable forest ecosystems and management; a review article. Forest Science 42: 366-377. Wallin, D.O., F.J. Swanson and B. Marks 1994. Landscape pattern response to changes in pattern generation rules: land-use legacies in forestry. Ecol. Applic. 3: 569-580.

Weetman, G.F. 1998. A forest management perspective on sustained site productivity. For. Chron. 74: 75-77.

Whitney, G.G. 1986. Relation of Michigan's presettlement pine forest to substrate and disturbance history. Ecology 67: 1548-1559.

Woodley, S., G. Alward, L.I. Gutierrez, T. Hoekstra, B. Holt, L. Livingston, J. Loo, A. Skibicki, C. Williams and P. Wright. 1998. North American test of criteria and indicators of sustainable forestry. Final Report. Vol. 1. USDA Forest Service Research. 